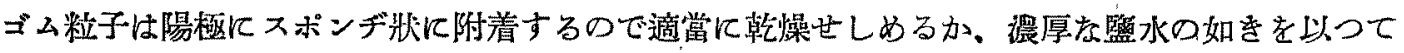
瞈水すればよく固着してフィルムを作るので西る。電解質の電解によるガスの發生と電極師被覆物 の溶解を防止せねばならない。電鈸用の掛金がこの方法で甘く作られれと云ふ。

パラの形でしかるゴムシートを用しると同荄な日的に仯するためにゴムセメントと加硫劑を混し たるのがコールパルク (Colvule) の名の下に發賣せられて居る。これは酎酸タンク、排風機、船底 等に塗布して腐蝕之磨耗を防ぐてとが出隶る。叉ゴムベルトの修理にb大變有效である。(此項䊏)、

\title{
本邦自動車タイヤー需給の概況
}

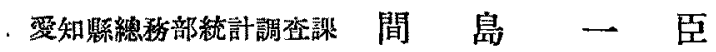

凘源、昭 10、5、4 號、11 25

1. は L が 己

南米の野生ゴムが初めて (1735 年)。組織的に研究されてから 200 年..米人グッドイヤー氏に低 つてその硫化作朋の發見.(1839 年) 以來 96 年. 更に自動車の發明 (1854 年) 以來約 80 年の歷 史を閱して、ゴムは現代文化に不可缺の重要資源の一つとなつた。

ゴムは彈力、伸縮、氣密、防水、屈曲、電氣絕緗、耐酸、耐アルカリ性等他の物質に容易に見ら，

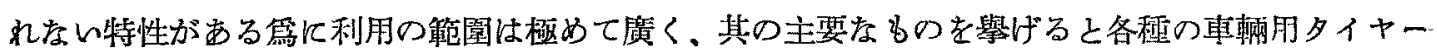

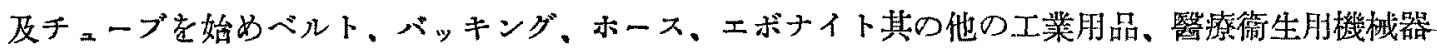
具、スポーツ肘品、家具敷物類、衣服及附屬品裝身具類、各程履物、玩具類其の他各力面に瓦り。

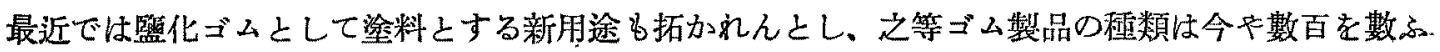
るも猶不足せる狀沇にある。

然し乍ら近代ゴム工業の大を篇せる主因は、何と言つても、自動車工業に件ふタイャー及チュー ブの製造。師ちタイヤー工業の隆盛となつたてとに低存してるる。

タイヤー及チューブはゴム製品中最も多量の原料ゴムを要する篇に、自動車に從屬すべき此の夕 イヤー工業は一般ゴム工業に燕大な影響を與ふると共に、斯業の消長は常にゴム方價膫落の主要な 原因々もをるるのであつて、殊に世界中自動車工業及タイヤ一工業の王座を占为る北米合策國の動 向に因り此の關係が最る顯著でする。我國近年に於けるゴム工業の膨脹も其の內容を檢すると種ふ の理由があるが、タイヤー工業の發達が其の有力な一因を煘すことを知る。

自動車は人及物質の運搬上極めて便利であるから平常に於てる益及重要になつて行くのは勿論。

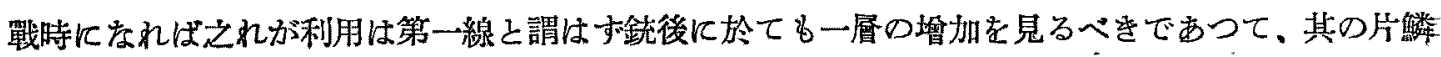
は滿洲及上海事變當時に於ても筧し知れよ5。隨つて我國產自動車工業つ確立と云ふ問題にも關聯 
そて、タイヤーの需給に就て一瞥を加人置くの要があらうと思ふのである。

\section{2 我國自動車臺数と內地自動自轉車臺數}

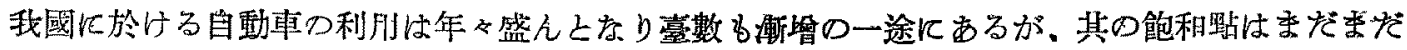

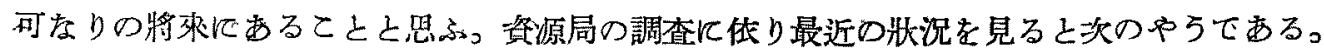

\section{(1) 自動車空}

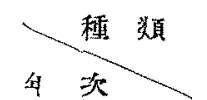

昭 和 5 年

昭 狆 6 年

昭机 7 年

昭 机 8 年

昭 相 9 年 (兓数)

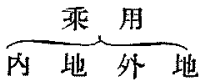

$52,862 \quad 5,864$

57,841

60,758

61,696

68,700

6,148

6,528

7,400

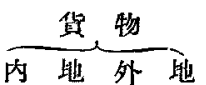

27,863

30,571

31,948

33,179

38,300

1,881

2,355

$\overbrace{\text { 内地 外 地 }}^{\text {特 }}$

丙地

合 郫

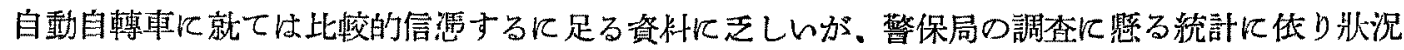
を䇉ると、

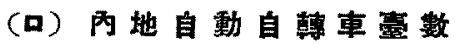

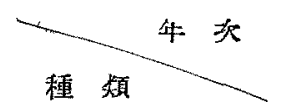

昭机 2 年 昭和 3 年

昭和 4 年

昭和 5 年

昭和 6 年

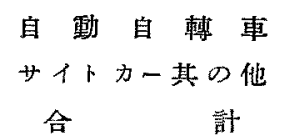

13,016
4,543
17,559

$$
\begin{array}{r}
13,998 \\
4,912
\end{array}
$$

14,588

5,535

14,282

14,638

18,910

20,123

8,854

11,610

( 23,136

26,248

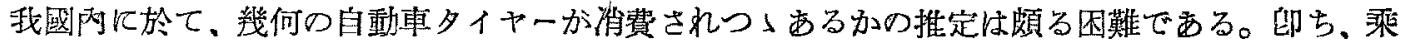

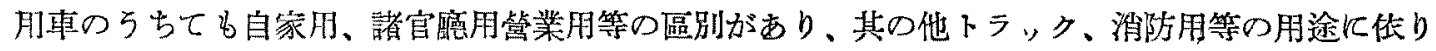
之等各々大小とりどりで、要するに車の用途、業熊、種類等に依つて走程や積㜞量を異にし、走路の 善惡がタイヤーの壽命に影響するととろ多い閔係もあるから、平均して 1 臺の車が 1 年何程のタイ

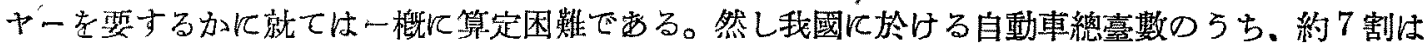
タクシーである實情に鑑み、タクシー附屬のタイャーの壽命を基礎に大體の推定は出來ると思ふの

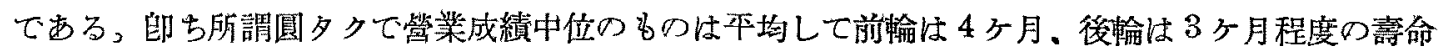
である。尤も之は東宗才於ける形况であるが、大阪、神户，其つ他之踓も大都市に於ては大體之 れと相似てるると思ふ。唯什舍にするものは相當惡路を走る關係上壽命は縮をる理屈だが、一方使

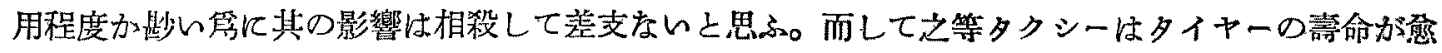

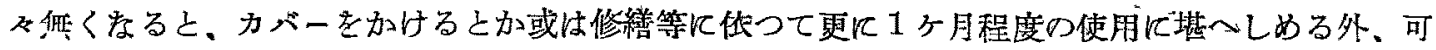

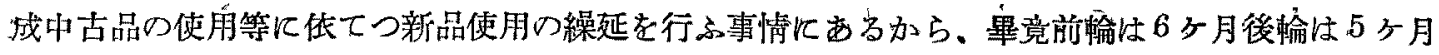




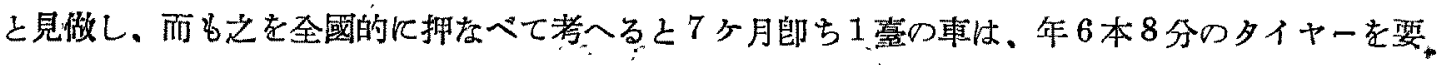
するものと推定して大過無かららと思ふ。之は約 7 割を占むるタクシー級に就てのてとであるが、

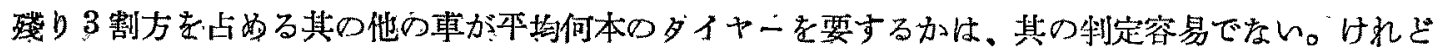

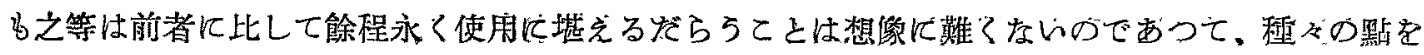

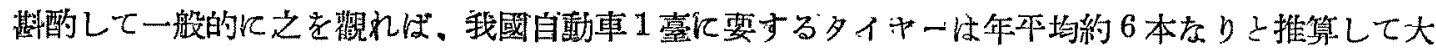
差索加ら5之考へる。

刃一方に於て、自動車總荎數が常に走行して居るかけのるのでなく、從つてタイヤー消費に直接 與ふるものを總㗌數の8 割と見做して推定すると、下表のやうとなる。

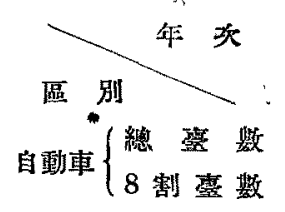

タイヤ一消費額

\section{我國自動車タイヤー推定消費额(本)}

\begin{tabular}{|c|c|c|c|c|}
\hline $\begin{array}{c}\text { 昭和 } 5 \text { 作 } \\
-\end{array}$ & 炤和 6 年 & 昭和 7 年 & 昭 和 8 年 & 昭和 9 年 \\
\hline 90,116 & ' 99,075 & 103,915 & 106,803 & 121,050 \\
\hline 72,093 & 79,260 & 83,132 & 85,442 & 96,840 \\
\hline 432,558 & 475,560 & 498,792 & 512,652 & 581,040 \\
\hline
\end{tabular}

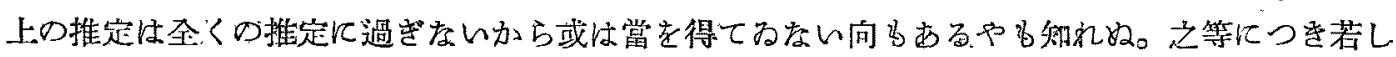

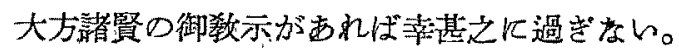

\section{4. 生 産 狀 況}

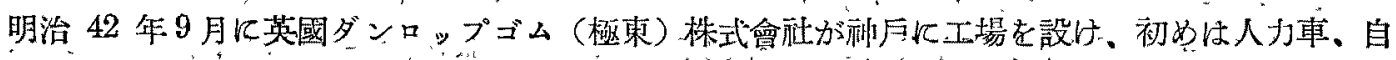
轉車のタイヤー及チューブ其の他のゴム製品の製造汇從つた樣で西るが、自動車のタイヤー及チ=

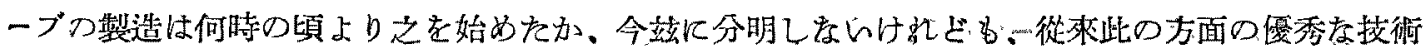

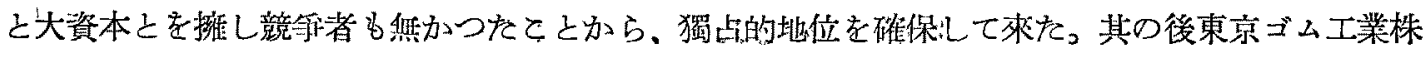

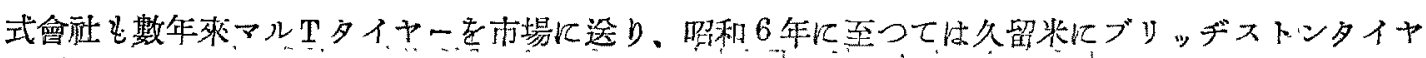

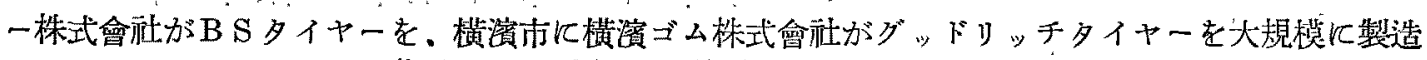

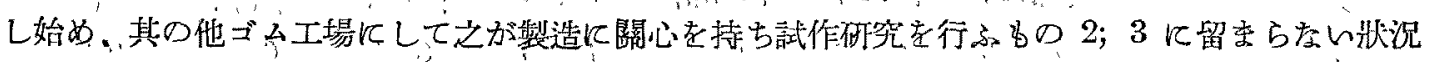

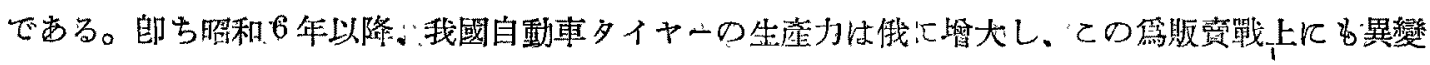

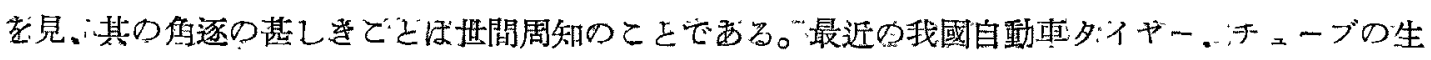

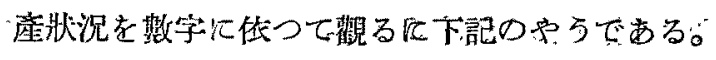

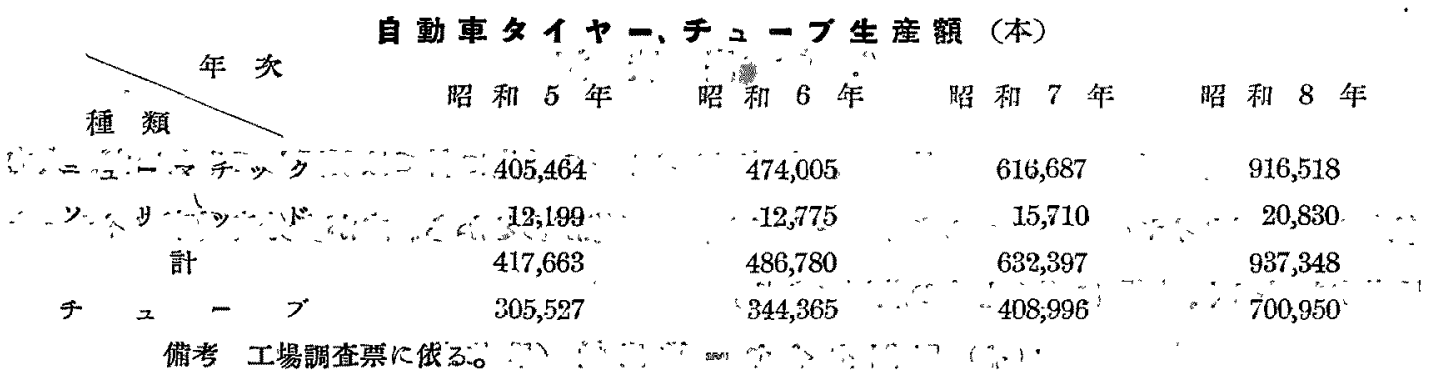


5. 輸 入 狀 況

自動車タイヤーの輸入は從來タイナー其のものとしての輸入と、自動車或はシャシーの輸入に件 つて之れに添附されて入る態樣とがする。其の狀況に就き觀察するに、

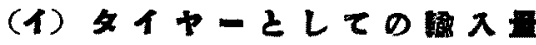

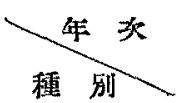
昭和 3 年 昭和 4 年 昭和 5 年 昭和 6 年 昭和 7 年 昭和 8 年 昭和 9 年

\section{合兽國上り}

其他の國上り

$\begin{array}{rrrrrrr}27,148 & 30,728 & 38,264 & 24,587 & 3,477 & 110 & - \\ 11,648 & 12,857 & 2,871 & 1,719 & 1,813 & 3 & - \\ 38,796 & 43,585 & 41,135 & 26,306 & 5,290 & 113 & 105 \\ 232,776 & 261,510 & 246,810 & 157,836 & 31,740 & 678 & 630\end{array}$

合 訫（懈）

偖考 一、大藏省外國貿易年表に依る。一、下段の換算本数はタイャー1本の平均重量を $10 \mathrm{~kg}$ として換 算した。

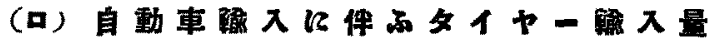

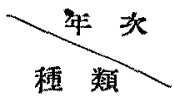

昭和 3 年 昭和 4 年 昭和 5 年 昭和 6 年 昭和 7 年 昭和 8 年 昭和 9 年

自動車䯬数

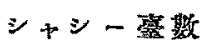

$\begin{array}{rrrrrrr}7,873 & 5,018 & 2,591 & 1,887 & 997 & 491 & 896 \\ 1,910 & 2,019 & 1,609 & 1,204 & 703 & 780 & 950 \\ 9,783 & 7,037 & 4,200 & 3,091 & 1,700 & 1,271 & 1,846 \\ 48,915 & 35,185 & 21,000 & 15,455 & 8,500 & 6,355 & 9,230\end{array}$

合換 算 本 教

$48,915 \quad 35,185$

21,000

15,455

8,500

9,230

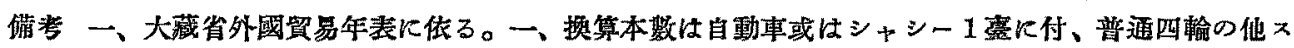
ペアー1本、許 5 本のタイヤーを添附する狀況故、咥数を 5 倍した。

以上の 2 表に示すタイヤーの輸入總量は下表の如し。

タイヤー铎入精量(單位本)

年 種
(1) 類
(a)
合

$\begin{array}{rrrrrrr}\text { 昭和 } 3 \text { 年 } & \text { 昭和 4年 } & \text { 昭和 5 年 } & \text { 昭和 6 年 } & \text { 昭和 7 年 } & \text { 昭和 8年 } & \text { 昭和 } 9 \text { 年 } \\ & & & & & & \\ 232,776 & 261,510 & 246,810 & 157,836 & 31,740 & 678 & 630 \\ 48,915 & 35,185 & 21,000 & 15,455 & 8,500 & 6,355 & 9,230 \\ 281,691 & 296,695 & 267,810 & 173,291 & 40,240 & 7,033 & 9,860\end{array}$

前表完るに昭和 4；5 年を頂點としてそれ以降タイャーの輸入は激減してるる。之は前項に述

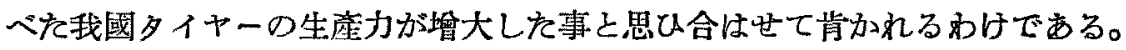

\section{6. 輸出 狀 況}

大藏省外國貿易年表には、輸出品表中、自動車タイヤーの輸出に付ては明記してるないが、人力 車或は自轉車タイヤー以外のゴムタイヤーと云ふ輸出記錄が西るから、之が多分自動車タイナーと 見做すを得へく、或别に觀ると次の狀況にある。 


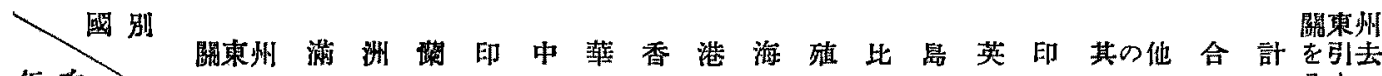
年次

\begin{tabular}{|c|c|c|c|c|c|c|c|c|c|c|}
\hline 昭和 6 年 & 863 & 一 & 4,917 & 2,881 & 1,509 & 1,380 & 615 & 129 & 20 & $.12,314$ \\
\hline 程和 7 年 & 2,875 & 1 & 4,344 & 2,209 & 972 & 1,403 & 1,733 & 2,943 & 989 & 17,469 \\
\hline 昭和 8 年 & 9,344 & 1,990 & 9,859 & 3,732 & 1,358 & 2,726 & 1,009 & 9,746 & 5,881 & 45,645 \\
\hline
\end{tabular}

偖考 大藏省外國貿易午表に依る。

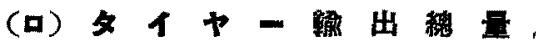

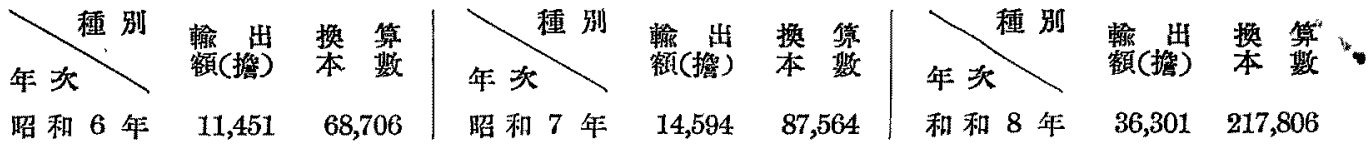
偖考（便）表をタイヤー1本の平均重量を $10 \mathrm{~kg}$ として换算した。

師ち以上に位れば、我國產自動車タイヤーは昭和 6 年を一䕎期として外國品を驅逐した計りでを く、一般輸出商品同樣に圓價安の波に乘つて俄に海外市場特に隣邦市場を目指して躍進してるる。

\section{7. タイャ一需給對照}

前述したるとてろに低り、一覽表を作成して其の需給狀況に就さて視るに下の通りでする。

$$
\text { タイヤー需給一監表(單位本) }
$$

\begin{tabular}{|c|c|c|c|c|c|c|c|c|}
\hline \multicolumn{4}{|c|}{ 年次 } & 歮 & 入 & 輸 & 差出消費 & 推定消凅 \\
\hline 昭 & 和 & 5 & 年 & 417,663 & 367,810 & - & - & 432,558 \\
\hline 昭 & 和 & 6 & 年 & 486,780 & 173,291 & 68,706 & 591,365 & 475,560 \\
\hline 昭 & 和 & 7 & 年: & 633,397 & 40,240 & 87,564 & 575,073 & 498,792 \\
\hline 昭 & 和 & 8 & 年 & 937,348 & 7,033 & 217,806 & 727,575 & 512,652 \\
\hline
\end{tabular}

上表に付て云へば、生產及輸出入に低る差引消費と推定消費との差額は、工場或は販賣店等に。 ストック或は商品見本として在るるの及軍部に消費されるタイヤーも含委れてるるやうで西るが。 大體以上を以て我國自動車タイヤーの需給概況を知るととが出來る5。

8. 原料ゴム消費より觀え゙タイヤー工業

我國に於て生ゴムの輸入は明治 13 年僅か 1 䎲に始り、昭和 9 年に於ては 7 萬县を突破してな る。其の間の狀勢を列べると。

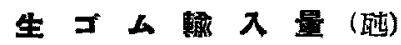

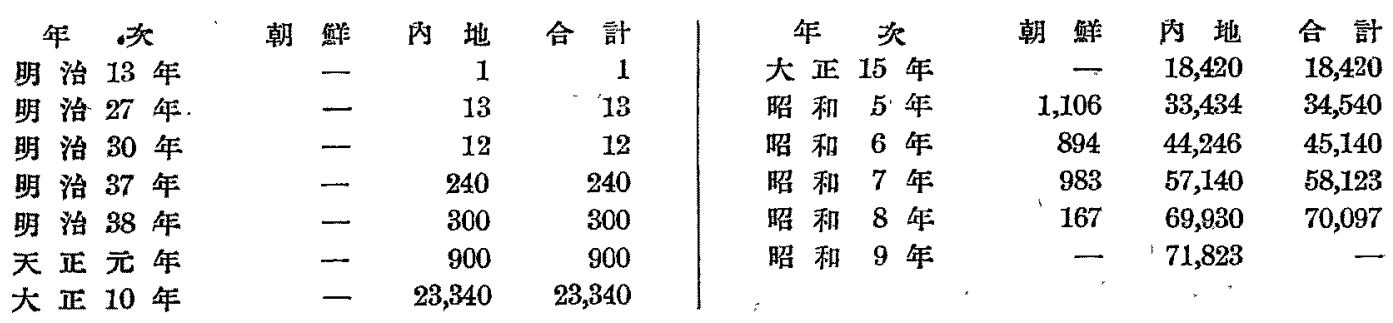


上表は素啨しん躍進の跡を示してわる。而して之等生ゴムが如何をる用途に消費さる」かを昭和 6； 7 年につき調查したるととろ記せば大略下の通りである。

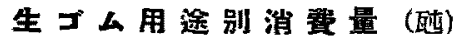

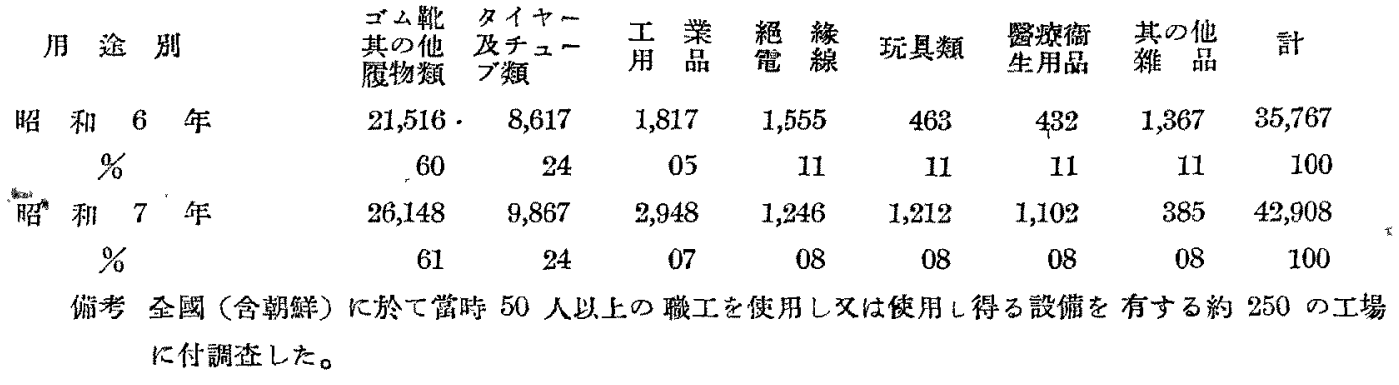

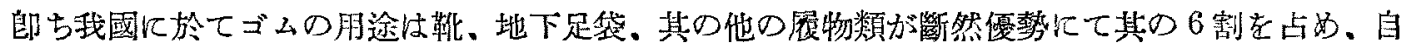

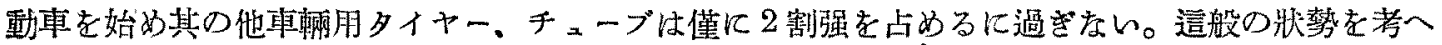

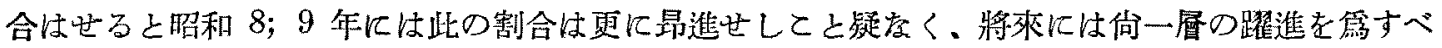

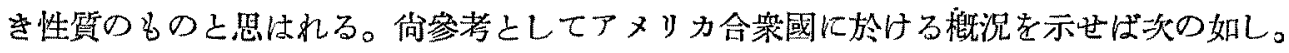

\begin{tabular}{|c|c|c|c|c|c|c|c|c|c|c|}
\hline 年 & 次 & 1921 & 1924 & 1925 & 1926 & 1927 & 1928 & 1929 & 1930 & 1931 \\
\hline 登 錄 & 数 (千 䇥) & 10,463 & 17,594 & 19,937 & 22,001 & 23,133 & 24,493 & 26,501 & 26,524 & 25,81 \\
\hline & 用 & 1,442 & 3,186 & 3,735 & 3,784 & 2,937 & 3,815 & 4,587 & 2,785 & 1,97 \\
\hline & トラック及バス & 155 & 417 & 531 & 517 & 465 & 543 & 771 & 571 & \\
\hline & 計 & 1,597 & 3,603 & 4,266 & 4,301 & 3,401 & 4,359 & 5.358 & 3,356 & \\
\hline & ケーデング & 21,857 & 38,804 & 45,729 & 46,277 & 48,536 & 58,537 & 54,981 & 40,772 & 38,9 \\
\hline & y y & 428 & 699 & 783 & 578 & 572 & 513 & 409 & 204 & \\
\hline 生本 & 訫 & 22,285 & 39,503 & 46,512 & 46,854 & 49,108 & 59,050 & 55,390 & 40,976 & 39 \\
\hline & $z-$ & 27,127 & 53,094 & 62,047 & 57,514 & 52,696 & 60,175 & 55,063 & 41,936 & 38,6 \\
\hline & ケーデング & - & $\therefore$ & - & - & - & 271,487 & 289,118 & 224,211 & 212,3 \\
\hline 喜消 & $\%$ & - & - & - & - & - & 12,220 & 8,990 & - 4,685 & 2,9 \\
\hline & $=-$ & - & - & - & - & - & $56,403$. & 56,683 & 46,234 & 40,0 \\
\hline & 計 & - & - & - & - & - & 340,110 & 354,791 & 275,120 & 255 \\
\hline 料 $\Xi^{\circ}$ & 總額 $(t)$ & 185,394 & 328,056 & 6,642 & 413,338 & 426,228 & 436,655 & 563,812 & 486,531 & 501, \\
\hline
\end{tabular}

\section{9. “无 す び}

以上述べたるところに依り。我國に於ける自動車タイヤ゙一は昭和 6 年を契機に其の生產設借を充

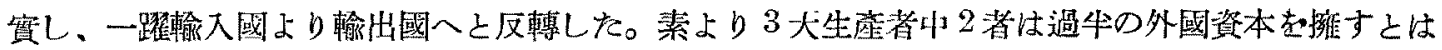
云へ、我國队に此の設備を有するととは以て人意を强うするに足る。

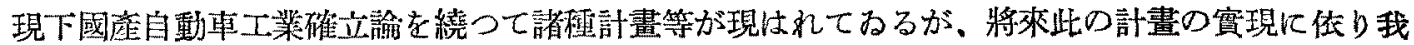

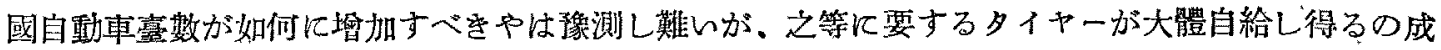
業を得てるると觀ても差支へなき現师にある。 
要之、我國は、將來自動車の利用大いに增加すべき滿洲、中華、荫洋等の苔國を控えて居り、他 方、原料ゴムの原產地にも比校的近在する外、斯工業經營上の諸條件にも惠れまてるるのであるか

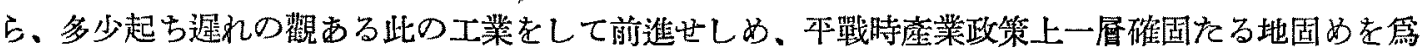
し置くべき必要があるのではないかと思はれる。この點に關し唯一つ大いに怔念とするところは。

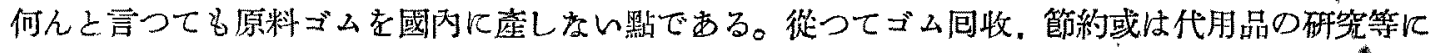
就ては。特に不断の努力が旰姴をととを痛切に憶ふのである。

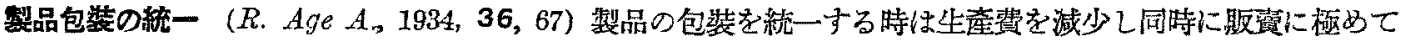
好都合になじ得る。今日の包装法は製品を先づボール箱や紙袋の如きののにれ、之を更に末箱、ブナイバー

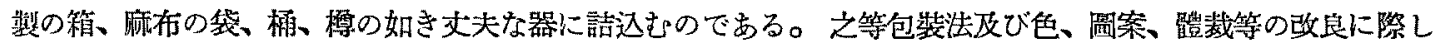

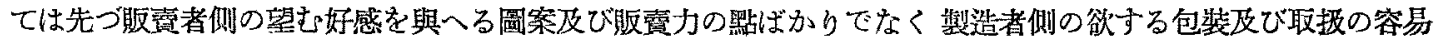

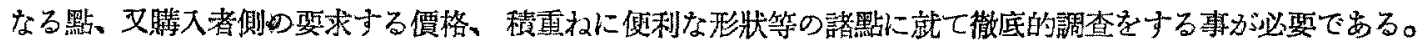
包裝の問題を研究するには先づ次の 3 項目に就て考へねばならない。第 1 體裁索統一し、人目を落く圖案とす

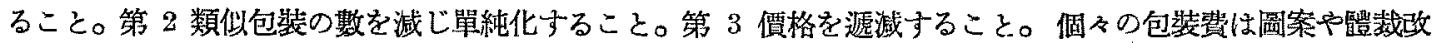

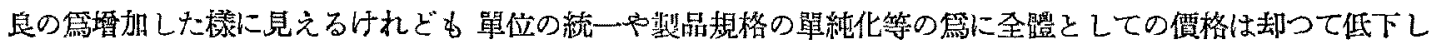
てるる。上記 3 項目を滿足する橆には次の諸點に就て考慮する事が必要でする。(1) 色、體裁、圖案、大きさ の何れか一つ或は之等 $2 ; 3$ の結合したものを標泎とすること。(2) 價格を明記し置くこと。(3) 凡ての棐品の

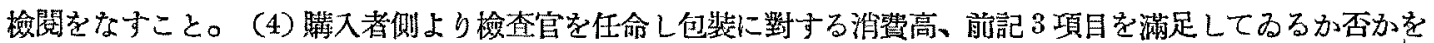
檢查せしらること。

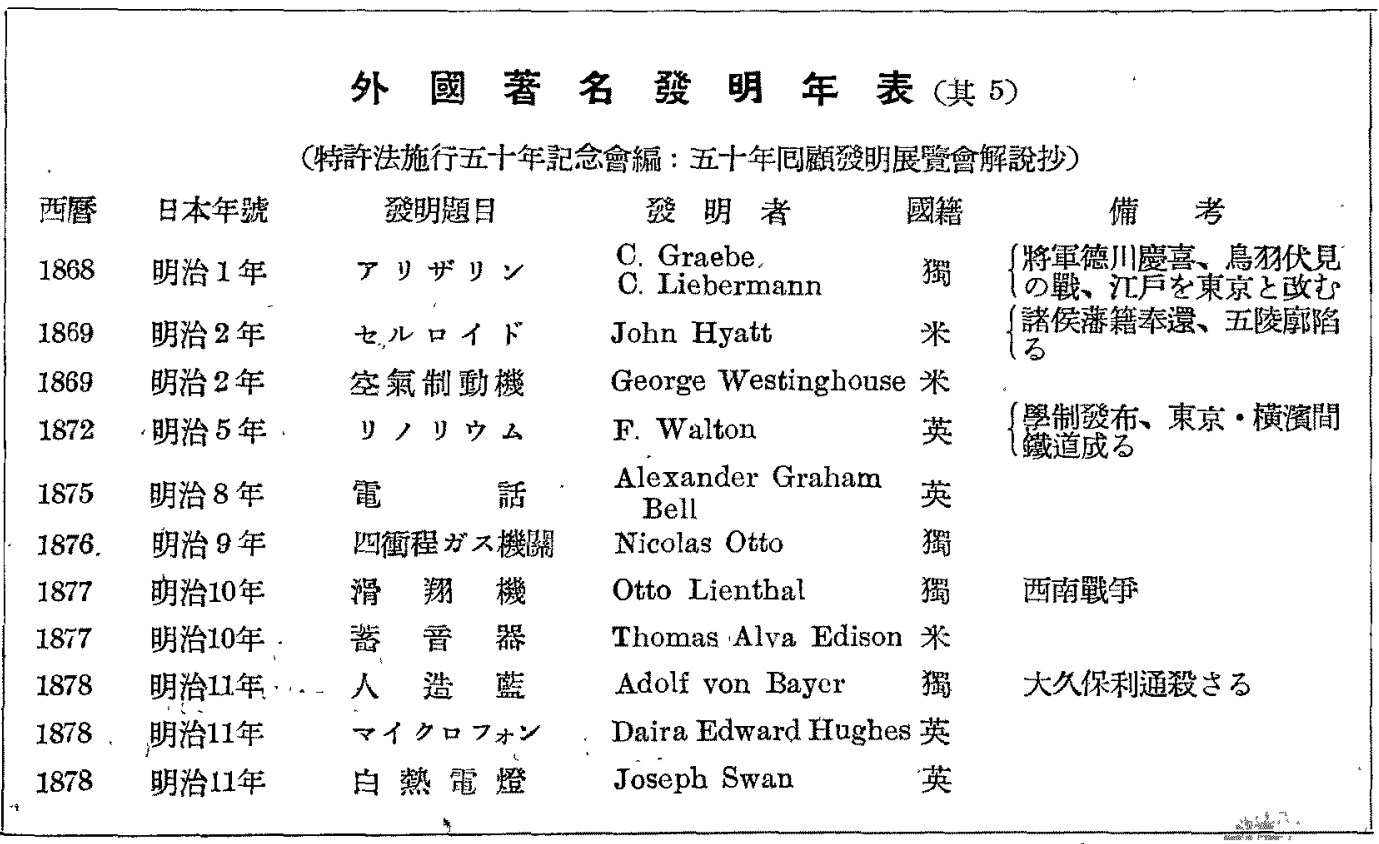

